\title{
Reactive nitrogen budget during the NASA SONEX Mission
}

\section{Citation}

Talbot, R. W., J. E. Dibb, E. M. Scheuer, Y. Kondo, M. Koike, H. B. Singh, L. B. Salas, et al. 1999. "Reactive Nitrogen Budget During the NASA SONEX Mission." Geophys. Res. Lett. 26 (20) (October 15): 3057-3060. doi:10.1029/1999gl900589.

\section{Published Version}

doi:10.1029/1999GL900589

\section{Permanent link}

http://nrs.harvard.edu/urn-3:HUL.InstRepos:14121841

\section{Terms of Use}

This article was downloaded from Harvard University's DASH repository, and is made available under the terms and conditions applicable to Other Posted Material, as set forth at http:// nrs.harvard.edu/urn-3:HUL.InstRepos:dash.current.terms-of-use\#LAA

\section{Share Your Story}

The Harvard community has made this article openly available.

Please share how this access benefits you. Submit a story.

\section{Accessibility}




\title{
Reactive Nitrogen Budget During the NASA SONEX Mission
}

\author{
R. W. Talbot, ${ }^{1}$ J. E. Dibb, ${ }^{1}$ E. M. Scheuer, ${ }^{1}$ Y. Kondo, ${ }^{2}$ M. Koike, ${ }^{2}$ H. B. Singh, ${ }^{3}$ \\ L. B. Salas, ${ }^{3}$ Y. Fukui, ${ }^{3}$ J. O. Ballenthin, ${ }^{4}$ R. F. Meads, ${ }^{4}$ T. M. Miller, ${ }^{4}$ \\ D. E. Hunton, ${ }^{4}$ A. A. Viggiano, ${ }^{4}$ D. R. Blake, ${ }^{5}$ N. J. Blake, ${ }^{5}$ E. Atlas, ${ }^{6}$ \\ F. Flocke, ${ }^{6}$ D. J. Jacob, ${ }^{7}$ and L. Jaegle ${ }^{7}$
}

\begin{abstract}
The SASS Ozone and Nitrogen Oxides Experiment (SONEX) over the North Atlantic during October/November 1997 offered an excellent opportunity to examine the budget of reactive nitrogen in the upper troposphere ( 8 - $12 \mathrm{~km}$ altitude). The median measured total reactive nitrogen $\left(\mathrm{NO}_{\mathrm{y}}\right)$ mixing ratio was 425 parts per trillion by volume (pptv). A data set merged to the $\mathrm{HNO}_{3}$ measurement time resolution was used to calculate $\mathrm{NO}_{\mathrm{y}}\left(\mathrm{NO}_{\mathrm{y}}\right.$ sum) by summing the reactive nitrogen species (a combination of measured plus modeled results) and comparing it to measured $\mathrm{NO}_{\mathrm{y}}$ (NO $\mathrm{N}_{\mathrm{y}}$ meas.). Comparisons were done for tropospheric air $\left(\mathrm{O}_{3}<100\right.$ parts per billion by volume (ppbv)) and stratospherically influenced air $\left(\mathrm{O}_{3}>100 \mathrm{ppbv}\right)$ with both showing good agreement between $\mathrm{NO}_{\mathrm{y}}$ sum and $\mathrm{NO}_{\mathrm{y}}$ meas. (slope $>0.9$ and $\mathrm{r}^{2} \approx 0.9$ ). The total reactive nitrogen budget in the upper troposphere over the North Atlantic appears to be dominated by a mixture of $\mathrm{NO}_{\mathrm{x}}\left(\mathrm{NO}+\mathrm{NO}_{2}\right.$ ), $\mathrm{HNO}_{3}$, and PAN. In tropospheric air median values of $\mathrm{NO}_{\mathbf{x}} / \mathrm{NO}_{\mathbf{y}}$ were $\approx 0.25, \mathrm{HNO}_{3} / \mathrm{NO}_{\mathrm{y}} \approx 0.35$ and $\mathrm{PAN} / \mathrm{NO}_{\mathrm{y}} \approx 0.17$. Particulate $\mathrm{NO}_{3}{ }^{-}$and alkyl nitrates together composed $<10 \%$ of $\mathrm{NO}_{y}$, while model estimated $\mathrm{HNO}_{4}$ averaged $12 \%$. For the air parcels sampled during SONEX, there does not appear to be a large reservoir of unidentified $\mathrm{NO}_{\mathrm{y}}$ compounds.
\end{abstract}

\section{Introduction}

Reactive nitrogen compounds in the Earth's troposphere, primarily believed to be present as $\mathrm{NO}, \mathrm{NO}_{2}, \mathrm{HONO}, \mathrm{HNO}_{3}, \mathrm{HNO}_{4}$, $\mathrm{NO}_{3}, \mathrm{~N}_{2} \mathrm{O}_{5}, \mathrm{CH}_{3} \mathrm{C}(\mathrm{O}) \mathrm{OONO}_{2}(\mathrm{PAN}), \mathrm{RONO}_{2}$ (alkyl nitrates), and particulate $\mathrm{NO}_{3}{ }^{-}$, constitute important controls on $\mathrm{O}_{3}$, oxidant, and acidity levels on a global scale. The collective sum of these species, commonly referred to as total reactive odd-nitrogen $\left(\mathrm{NO}_{\mathrm{y}}\right)[$ Fahey et al., 1985], is a quantity useful for general characterization of air parcels in rural and remote atmospheres. Direct measurements of $\mathrm{NO}_{\mathrm{y}}$ and its suspected dominant components show good agreement at most continental sites at part per billion by volume (ppbv) mixing ratios where a simple mixture of $\mathrm{NO}_{\mathrm{x}}, \mathrm{HNO}_{3}$, and PAN

Institute for the Study of Earth, Oceans, and Space, University of New Hampshire, Durham

${ }^{2}$ Solar-Terrestrial Environmental Laboratory, Nagoya University, Toyokawa, Japan.

${ }^{3}$ NASA Ames Research Center, Moffett Field, California.

${ }^{4}$ Air Force Research Laboratory/VSBP, Hanscom Air Force Base, Massachusetts.

${ }^{5}$ Department of Chemistry, University of California - Irvine, Irvine, California.

${ }^{6}$ Atmospheric Chemistry Division, National Center for Atmospheric Research, Boulder, Colorado.

'Department of Earth and Planetary Sciences, Harvard University, Cambridge, Massachusetts.

\section{Copyright 1999 by the American Geophysical Union.}

Paper number 1999GL900589.

0094-8276/99/1999GL900589\$05.00 comprise $>90 \%$ of total $\mathrm{NO}_{\mathrm{y}}$ [Parish et al., 1993; Sandholm et al., 1994].

At remote locations comparison of $\mathrm{NO}_{\mathrm{y}}$ meas. and $\mathrm{NO}_{\mathrm{y}}$ sum at hundreds of parts per trillion by volume (pptv) typically show disagreement of 30-50\% [Fahey et al., 1986; Ridley, 1991; Sandholm et al., 1994; Atlas et al., 1992a; Crosley, 1996; Kondo et al., 1997a]. Measurement problems at low mixing ratios for individual reactive nitrogen species, overestimation of $\mathrm{NO}_{y}$ meas. due to non-reactive nitrogen compounds [Crosley et al., 1996; Bradshaw et al., 1998] and possible inclusion of unidentified $\mathrm{NO}_{\mathrm{y}}$ compounds (e.g., alkyl nitrates) in $\mathrm{NO}_{\mathrm{y}}$ meas. [Fahey et al., 1986; Atlas et al., 1992a] have been proposed as explanations.

In this paper we present a summary comparison between $\mathrm{NO}_{\mathrm{y}}$ measured directly with a gold catalytic converter [Kondo et al., $1997 \mathrm{~b}$ ] and the sum of the individually measured species NO, $\mathrm{HNO}_{3}, \mathrm{PAN}, \mathrm{PPN}$, alkyl nitrates, plus modeled $\mathrm{NO}_{2}, \mathrm{HONO}$, $\mathrm{HNO}_{4}, \mathrm{~N}_{2} \mathrm{O}_{5}$, and $\mathrm{NO}_{3}$ over the North Atlantic during October/November 1997. The SONEX data represent the most complete set of measurement and model estimated parameters collected to date for the upper troposphere, and provide a good basis for examining our understanding of the $\mathrm{NO}_{y}$ budget in this region of the troposphere. The data were obtained in or near the North Atlantic flight corridor where $\approx 700$ commercial aircraft traverse it each day at 9 - $12 \mathrm{~km}$ altitude between North America and Europe. Air parcels sampled in this region should represent a combination of processed continental and "fresh" aircraft emissions.

\section{Methods}

The SONEX mission was conducted aboard the NASA Ames DC-8 research aircraft with the majority $(>95 \%)$ of the data collected at $8-12 \mathrm{~km}$ altitude. The aircraft operated from three base stations: Bangor, Maine (four flights), Shannon, Ireland (four flights), and the Azore Islands (one flight) and transits in between these locations. The details of the mission are sumnarized in the companion overview paper [Singh et al., this issue]. All of the data collected on these flights was used in this analysis to constitute a total of 15 science missions $(\approx 120$ flight hours of data).

Nitric oxide (NO) and $\mathrm{NO}_{\mathrm{y}}$ were sampled through a rear-facing (to help exclude aerosols $>1 \mu \mathrm{m}$ diameter) heated $\left(50^{\circ} \mathrm{C}\right)$ PFA teflon tube (6 mm ID) at 1 standard liter per minute (SLPM) flow rate and detected as NO using chemiluminescence [Kondo et al., 1997b]. NO was catalytically converted to NO at $50 \mathrm{hPa}$ on the surface of a gold tube heated to $300^{\circ} \mathrm{C}$ with addition of $\mathrm{CO}$. The precision of 10 second $\mathrm{NO}$ and $\mathrm{NO}_{\mathrm{y}}$ measurements at $10 \mathrm{~km}$ altitude estimated from two sigma photon count fluctuations was 6 and 19 pptv at 100 and 800 pptv respectively. The absolute accuracy was estimated to be 8 and $10 \%$ for $\mathrm{NO}$ and $\mathrm{NO}_{\mathrm{y}}$.

Nitric acid was measured using the mist chamber (MC) technique [Talbot et al., 1997, 1999]. The instrument utilized a heated $\left(35^{\circ} \mathrm{C}\right)$ fast flowing (1000-3000 SLPM) fused-silica coated manifold $(\approx 50 \mathrm{~mm}$ ID) with the capability to conduct standard 


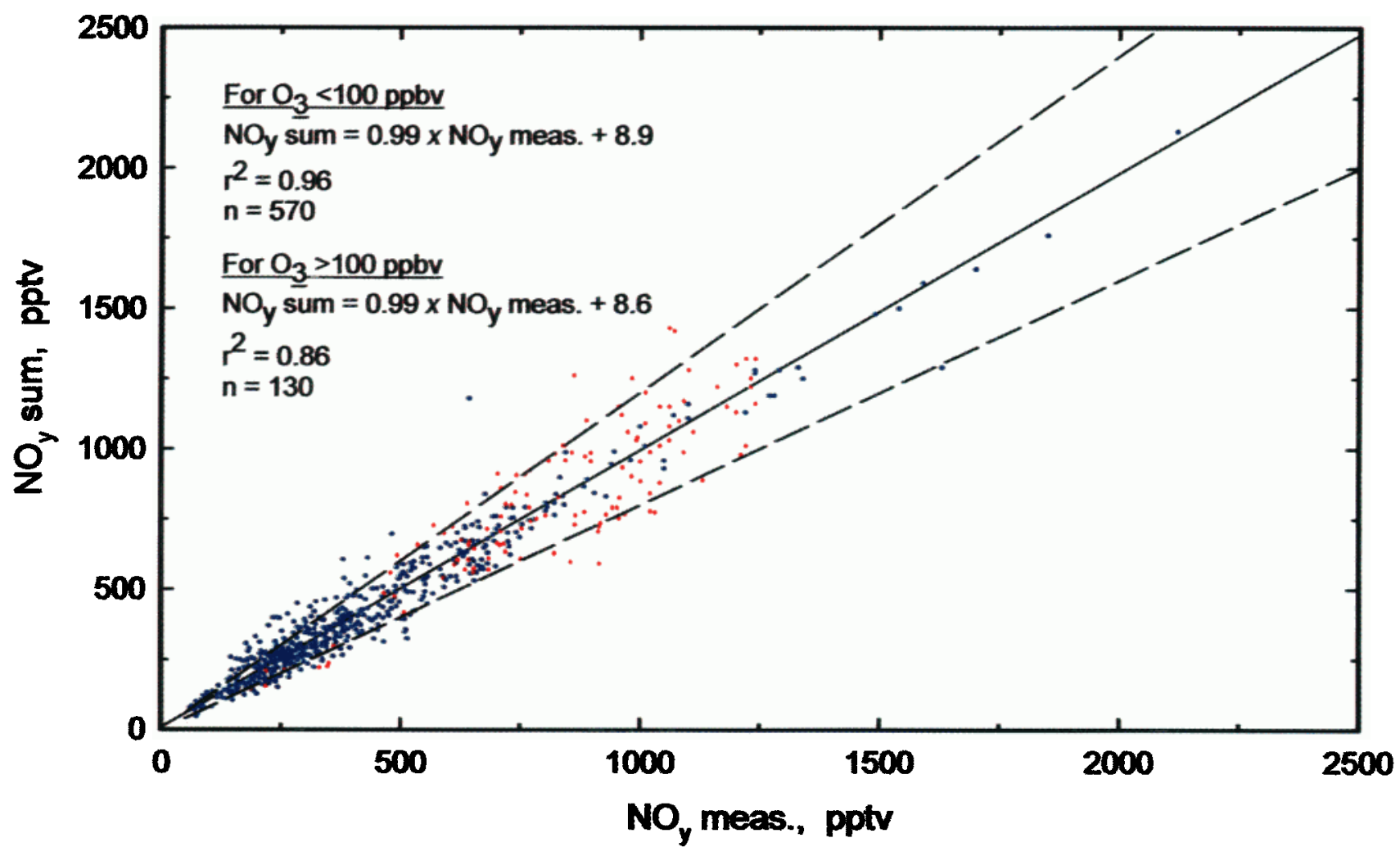

Figure 1. Linear least squares relationship between $\mathrm{NO}_{\mathrm{y}}$ meas. and $\mathrm{NO}_{\mathrm{y}}$ sum in the middle and upper troposphere $(8-12.5 \mathrm{~km}$ altitude) over the North Atlantic. Blue solid circles represent the relationship for $\mathrm{O}_{3}<100 \mathrm{ppbv}$ and the red $\mathrm{O}_{3}>100$ ppbv. Only one regression line is shown since the two overlap identically, with $\pm 20 \%$ bounds indicated by dashed lines.

additions of $\mathrm{HNO}_{3}$ down $\approx 95 \%$ of the entire length of the inlet. At mixing ratios above 100 pptv the overall uncertainty is $15-20 \%$, increasing to $25-30 \%$ below 100 pptv. Nitric acid was also measured by a new chemical ionization mass spectrometer (CIMS) instrument [Miller et al.,1999]. Calibration and offset issues are currently being resolved for this instrument, so associated measurement uncertainties have not been fully assessed. Thus, these data have not been included in this analysis of the $\mathrm{NO}_{\mathrm{y}}$ budget, but in general the two data sets for $\mathrm{HNO}_{3}$ agreed within $25 \%$.

Peroxyacetyl nitrate (PAN) and peroxypropionyl nitrate (PPN) were measured through a rear-facing inlet $(6 \mathrm{~mm} \mathrm{ID)} \mathrm{composed} \mathrm{of}$ heated $\left(20^{\circ} \mathrm{C}\right)$ PFA teflon tubing with a flow rate of 5 SLPM. PAN and PPN were cyrogenically trapped from ambient air and quantified subsequently by electron capture gas chromatography [Singh and Salas, 1983]. The uncertainty for PAN and PPN is 20\%.

Alkyl nitrates (methyl nitrate, ethyl nitrate, 1-propyl nitrate, 2propyl nitrate, and 2-butyl nitrate) were sampled through a $6 \mathrm{~mm}$ ID stainless steel tube into passivated stainless steel canisters and pressurized to $2750 \mathrm{hPa}$ with a metal bellows pump. The canisters were shipped back to the laboratory where the alkyl nitrates were cyrogenically trapped and measured using electron capture and mass spectrometry detection coupled with gas chisnatography [Atlas et al., 1992b]. The overall uncertainty in the alkyl nitrate data is $20 \%$. In addition, alkyl nitrates were measured along with PAN and PPN in near real-time and agreed within $20 \%$ with the canister method. For this paper we utilized the canister data set which had better overlap with the time base used in our budget analysis.

A diel steady-state model [Jaegle et al., this issue] was used to calculate the unmeasured species $\mathrm{NO}_{2}, \mathrm{NO}_{3}, \mathrm{~N}_{2} \mathrm{O}_{5}, \mathrm{HONO}$, and $\mathrm{HNO}_{4}$. The model was constrained with observed $\mathrm{NO}, \mathrm{CO}, \mathrm{H}_{2} \mathrm{O}$, $\mathrm{CH}_{4}$, hydrocarbons, pressure, temperature, aerosol surface area, and
UV actinic flux. Modeled $\mathrm{HO}_{2}$ was used to calculate $\mathrm{NO}_{2}$. The error in evaluating $\mathrm{NO}_{2}$ could be as large as $50 \%$, which is derived from the uncertainties in measured $\mathrm{NO}, \mathrm{O}_{3}$, and the rate constants for $\mathrm{NO}$ $+\mathrm{O}_{3}$ and $\mathrm{NO}_{2}$ photolysis.

\subsection{Database}

Although each of the participating groups reported individual flight data files to the SONEX archive (publically available on Cloudl.nasa.ames.gov at NASA Ames Research Center), we used data files merged to the $\mathrm{HNO}_{3}$ time resolution for the analyses reported in this paper. This provided measurements and associated model-estimated $\mathrm{NO}_{2}, \mathrm{HONO}, \mathrm{HNO}_{4}, \mathrm{~N}_{2} \mathrm{O}_{5}$, and $\mathrm{NO}_{3}$ on the same time base [Jaegle et al., this issue]. Since particulate- $\mathrm{NO}_{3}{ }^{-}$was measured during SONEX with approximately 10 minute time resolution, we did not include it in the data analysis. The median value of particulate- $\mathrm{NO}_{3}^{-}$was 15 pptv [Dibb et al., 1999] which represented $<5 \%$ of the $\mathrm{NO}_{\mathrm{y}}$ and its omission for our budget analysis does not significantly influence the conclusions presented here.

We further narrowed the selected data set based on two criteria: (1) a solar zenith angle $<85^{\circ}$ and, (2) measurement intervals where $\mathrm{NO}, \mathrm{HNO}_{3}, \mathrm{PAN}$, and $\mathrm{NO}_{\mathrm{y}}$ were all reported with a time overlap of $>50 \%$. This reduced the data points for our analysis from several thousand to 700 . We believe that this final breakdown provides a reasonably consistent set of measurement and model products to evaluate the upper tropospheric $\mathrm{NO}_{\mathrm{y}}$ budget over the North Atlantic.

\section{The NO Budget}

The $\mathrm{NO}_{\mathrm{y}}$ sum compared to $\mathrm{NO}_{\mathrm{y}}$ meas. showed a high degree of correlation over the range of $\mathrm{NO}_{\mathrm{y}}$ mixing ratios from $\approx 70-1500$ pptv [Figure 1]. Here $\mathrm{NO}_{\mathrm{y}}$ sum represents the measured species NO, 

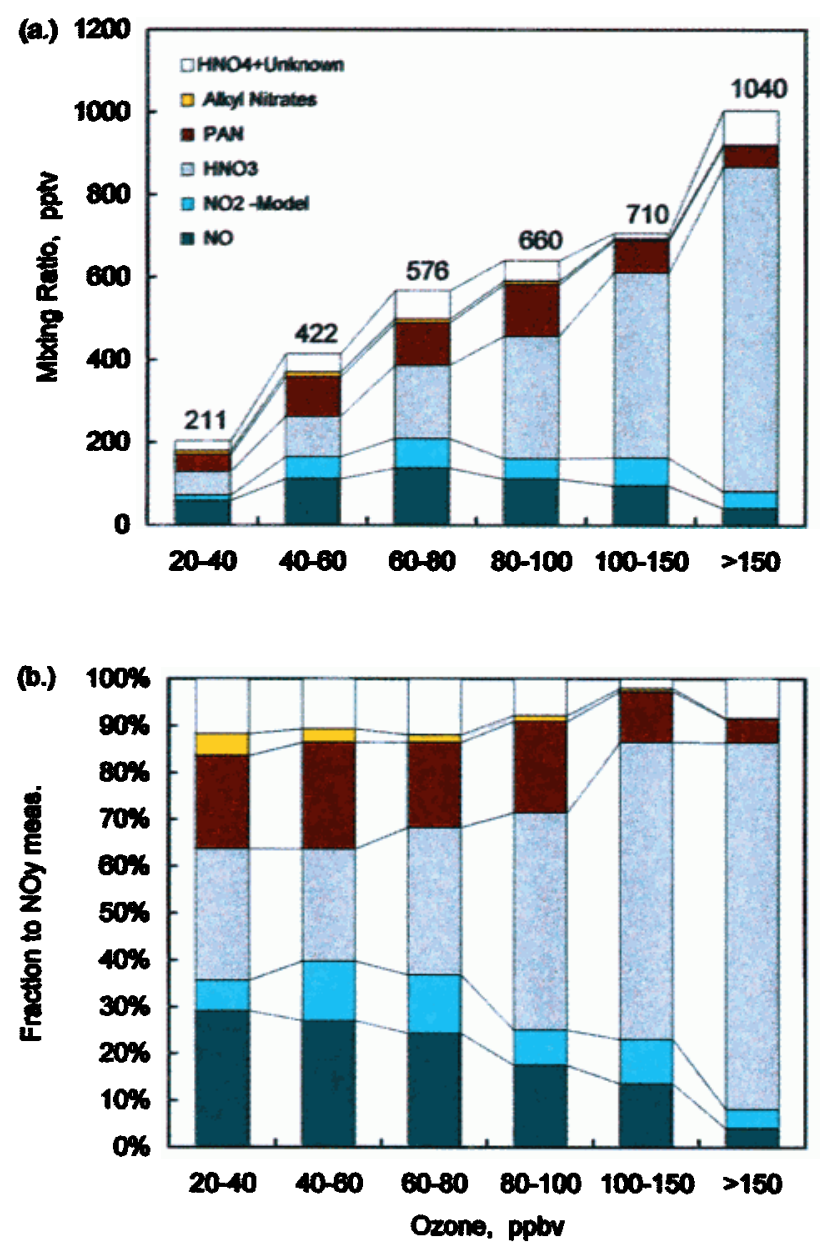

Figure 2. (a) Average value of various reactive nitrogen species as a function of binned $\mathrm{O}_{3}$ mixing ratios. The height of the stacked groupings represent the sum of the individual components and the value above it is average $\mathrm{NO}_{y}$ meas. The uncolored area includes model calculated $\mathrm{HNO}_{4}$ plus the remaining difference in $\mathrm{NO}_{\mathrm{y}}$ meas. and $\mathrm{NO}_{\mathrm{v}}$ sum. (b) Fraction of each species as shown in (a) to $\mathrm{NO}_{\mathrm{y}}$ meas. as a function of binned $\mathrm{O}_{3}$ mixing ratios.

$\mathrm{HNO}_{3}$, PAN, PPN, methyl nitrate, ethyl nitrate, 1-propyl nitrate, 2propyl nitrate, 2-butyl nitrate, plus modeled $\mathrm{NO}_{2}, \mathrm{HONO}, \mathrm{HNO}_{4}$, $\mathrm{N}_{2} \mathrm{O}_{5}$, and $\mathrm{NO}_{3}$. The dashed lines depicted in Figure 1 indicate $\pm 20 \%$ values for the regression relationship, with $98 \%$ of the data falling within these bounds.

As presented in Figure 1, the data was broken into two groups based on the $\mathrm{O}_{3}$ mixing ratio to generally separate tropospheric $\left(\mathrm{O}_{3}\right.$ $<100 \mathrm{ppbv})$ from stratospherically influenced air parcels $\left(\mathrm{O}_{3}>100\right.$ ppbv). The correlation between $\mathrm{NO}_{\mathrm{y}}$ sum and $\mathrm{NO}_{\mathrm{y}}$ meas. was the same in both types of air parcels indicating no significant bias in comparing regions comprised of numerous reactive nitrogen species (troposphere) with another dominated by $\mathrm{HNO}_{3}$ (stratosphere). The few large mixing ratios of $\mathrm{NO}_{\mathrm{y}}$ for the tropospheric case represent sampling of recent aircraft emissions where NO comprised $\geq 80 \%$ of the $\mathrm{NO}_{\mathrm{y}}$ species. The lowest mixing ratios of $\mathrm{NO}_{\mathrm{y}}$ denote tropical air parcels sampled south of the Azores where mixing ratios (pptv) of the various species were about 10 (NO), $3\left(\mathrm{NO}_{2}\right.$ calc.), 35 $\left(\mathrm{HNO}_{3}\right), 10$ (PAN), 5 (sum of alkyl nitrates), and 5 ( $\mathrm{HNO}_{4}$ calc.).

In Figure 2 the median values of the various reactive nitrogen species are shown as a function of binned $\mathrm{O}_{3}$ mixing ratios. In tropospheric air $\mathrm{NO}_{x}$ had a median mixing ratio of $150 \mathrm{pptv}, \mathrm{HNO}_{3}$ 130 pptv, and PAN 80 pptv. The relatively high values of $\mathrm{NO}_{\mathrm{x}}$ probably reflect inputs from aircraft, lightning, and surface pollution uplifted by convection [Thompson et al., this issue]. At $\mathrm{O}_{3}$ mixing ratios greater than $100 \mathrm{ppbv}$ stratospheric influence was evident based on concomitant ${ }^{7} \mathrm{Be}$ concentrations $>1000$ femtocurries $\left(10^{-15} \mathrm{Ci}\right)$ per standard cubic meter and $\mathrm{CO}$ mixing ratios $<50 \mathrm{ppbv}$ [Dibb et al., 1999]. The fraction of $\mathrm{HNO}_{3}$ in these air parcels (i.e., $\mathrm{HNO}_{3} / \mathrm{NO}_{\mathrm{y}}$ ) progressively increased from the middle troposphere to the lower stratosphere comprising as much as $80 \%$ of $\mathrm{NO}_{\mathbf{y}}$.

Median values of the ratios of $\mathrm{NO}_{x}, \mathrm{HNO}_{3}$, and $\mathrm{PAN}$ to $\mathrm{NO}_{\mathrm{y}}$ meas. in tropospheric air showed that overall $\mathrm{NO}_{\mathrm{r}}$ composed $\approx 25 \%$ of $\mathrm{NO}_{\mathrm{y}}, \mathrm{HNO}_{3} \approx 35 \%$, and $\mathrm{PAN} \approx 17 \%$. The alkyl nitrates collectively averaged about $10 \mathrm{pptv}$, and represented $\leq 5 \%$ of $\mathrm{NO}_{\mathrm{y}}$. Particulate reactive nitrogen was sampled to some (unknown) degree by the $\mathrm{NO}_{\mathrm{y}}$ instrument, some of which could have been present in unidentified forms. Our model calculations predict from $0.1-100 \mathrm{pptv}$ of various unmeasured reactive nitrogen species, with $\mathrm{HNO}_{4}$ being the most important one accounting for an average of $12 \pm 9 \%$ (i.e., $55 \pm 30 \mathrm{pptv}$ ) of $\mathrm{NO}_{\mathrm{y}}$ sum. In addition, positive interference in $\mathrm{NO}_{\mathrm{y}}$ meas. by non-reactive nitrogen compounds

(a.)
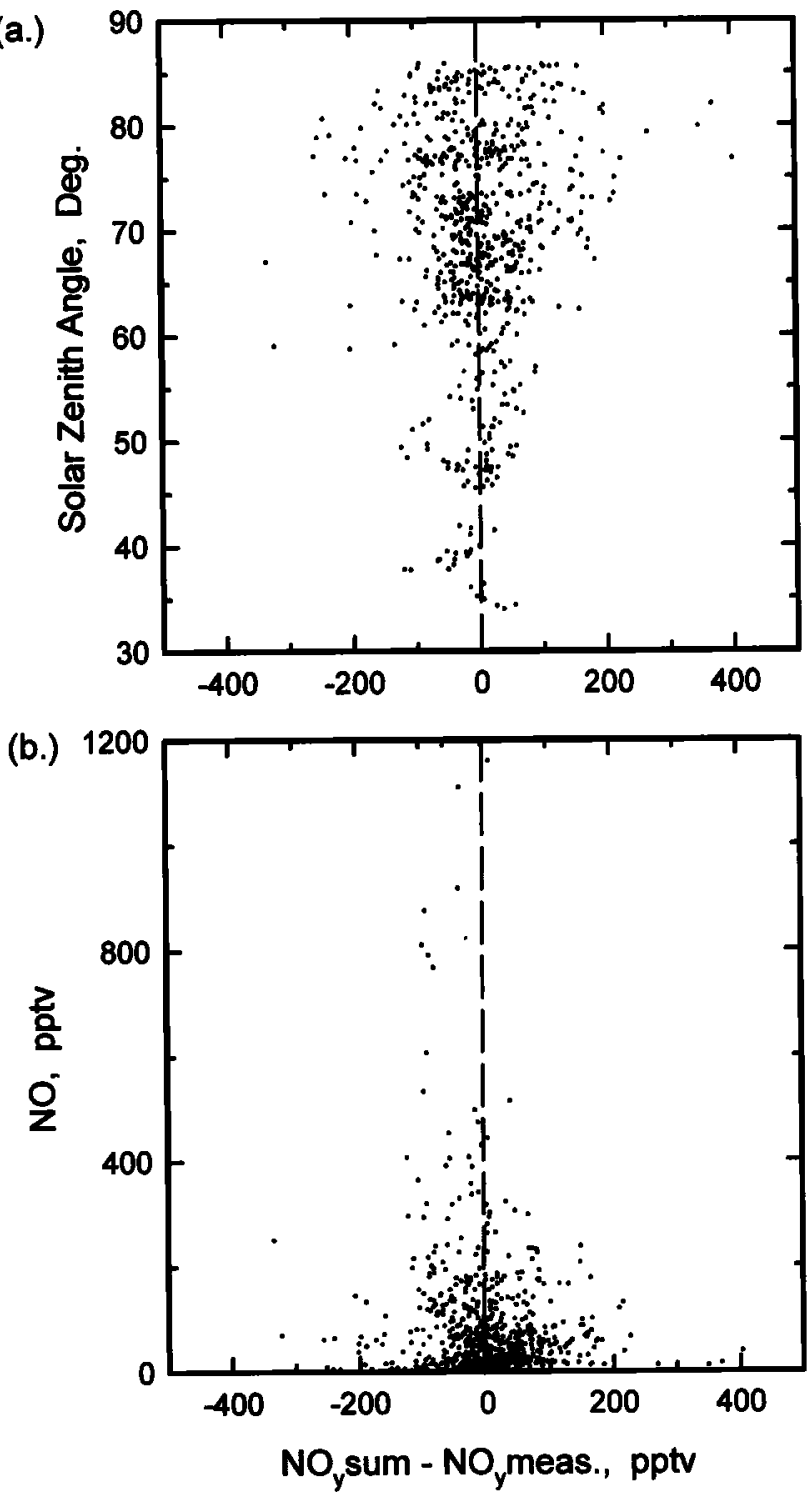

Figure 3. Difference between $\mathrm{NO}_{\mathrm{y}}$ sum and $\mathrm{NO}_{\mathrm{y}}$ meas. as a function of solar zenith angle (a) and NO mixing ratio (b). 
(e.g., $\mathrm{NH}_{3}$ and $\mathrm{HCN}$ ) [Kliner et al., 1997; Bradshaw et al., 1998] is a general concern, but seemingly a small one with regard to the SONEX data [Koike et al., 1999].

To look for likely factors which may have contributed to systematic differences in $\mathrm{NO}_{\mathrm{y}}$ sum and $\mathrm{NO}_{\mathrm{y}}$ meas., we plotted the difference, $\mathrm{NO}_{\mathrm{y}}$ sum. - $\mathrm{NO}_{\mathrm{y}}$ meas., as a function of various parameters including $\mathrm{HNO}_{3}, \mathrm{PAN}, \mathrm{O}_{3}, \mathrm{CO}, \mathrm{C}_{2} \mathrm{H}_{2} / \mathrm{CO}$ and modeled $\mathrm{HNO}_{4}$. No significant trends were identified. This suggests that measurement bias or chemical environments sampled during SONEX were not a major factor influencing the agreement between $\mathrm{NO}_{y}$ sum. and $\mathrm{NO}_{\mathrm{y}}$ meas. An interesting result was found with regard to solar zenith angle (Figure 3a); the difference in $\mathrm{NO}_{\mathrm{y}}$ sum. and $\mathrm{NO}_{\mathrm{y}}$ meas. increased with larger solar zenith angles. A possible explanation for this trend is that at high solar zenith angles NO is at mixing ratios $<20$ pptv (Figure $3 \mathrm{~b}$ ) due to slowed photoysis of $\mathrm{NO}_{2}$. The uncertainty in measured $\mathrm{NO}$ is greatest here $(\approx 25-30 \%)$, which then propagates to larger variability in important model calculated species such as $\mathrm{NO}_{2}$ and $\mathrm{HNO}_{4}$. Thus, $\mathrm{NO}_{\mathrm{y}}$ sum has greatest uncertainty at low mixing ratios of $\mathrm{NO}$, and propagation of the associated errors in $\mathrm{NO}_{\mathrm{y}}$ sum makes it potentially as large as $\pm 80 \%$. The increased scatter in the agreement between $\mathrm{NO}_{\mathrm{y}}$ sum and $\mathrm{NO}_{\mathrm{y}}$ meas. at high solar zenith angles (or low $\mathrm{NO}$ ) is attributed to this effect. The rather even distribution of positive and negative values of $\mathrm{NO}_{\mathrm{y}}$ sum $-\mathrm{NO}_{\mathrm{y}}$ meas. suggests that this is variation due to random errors rather than a serious bias in one of the terms.

Collectively the SONEX results indicate that $\mathrm{NO}_{x}, \mathrm{HNO}_{3}$ and PAN constitute about $80 \%$ of reactive nitrogen in the middle and upper troposphere over the North Atlantic. To narrow uncertainties in this type of budget analysis further, it requires development of techniques for reliable measurement of species such as $\mathrm{NO}_{2}$ and $\mathrm{HNO}_{4}$ in the remote troposphere. It is also necessary to continue to assess the conversion efficiency of $\mathrm{NO}_{\mathrm{y}}$ instruments for reactive and non-reactive nitrogen compounds under actual field conditions to better characterize the utility of $\mathrm{NO}_{\mathrm{y}}$ measurements in the troposphere.

Acknowledgments. We thank the flight and ground crews of the NASA Ames DC-8 research aircraft for a safe and very successful science mission. Support was received for this work from the NASA Atmospheric Effects on Aviation Project (AEAP) through the Subsonic Assessment (SASS) Office.

\section{References}

Atlas, E. L., B. A. Ridley, G. Hübler, J. G. Walega, M. A. Carroll, D. D. Montzka, B. J. Huebert, R. B. Norton, F. E. Grahek, and S. Schauffler, Partitioning and budget of $\mathrm{NO}_{\mathrm{y}}$ species during MLOPLEX, J. Geophys. Res., 97, 10,449-10,462, 1992a.

Atlas, E., S. M Schauffler, J. T. Merrill, C. J. Hahn, B. Ridley, J. Walega, J. Greenberg, L. Heidt, and P. Zimmerman, Alkyl nitrate and selected halocarbon measurements at Mauna Loa Observatory, Hawaii, $J$ Geophys. Res., 97, 10,331-10,348, 1992b.

Bradshaw, J., S. Sandholm, and R. Talbot, An update on reactive oddnitrogen measurements made during recent NASA Global Tropospheric Experiment programs, J. Geophys. Res., I03, 19,1290-19,148, 1998.

Crosley, D. R., NO ${ }_{\text {y }}$ Blue Ribbon panel, J. Geophys. Res., I01, 2049-2052, 1996.

Dibb, J. E., R. W. Talbot, E. M. Scheuer, Aerosol associated soluble ions in the upper troposphere/lower stratosphere over the North Atlantic during SONEX, J. Geophys. Res., in press, 1999.

Fahey, D. W., C. S. Eubank, G. Hubler, and F. C. Fehsenfeld, Evaluation of a catalytic reduction technique for the measurement of total reactive odd-nitrogen $\mathrm{NO}_{\mathrm{y}}$ in the atmosphere, J. Atmos. Chem., 3, 435-468, 1985 .
Fahey, D. W., G. Hubler, D. D. Parrish, E. J. Williams, R. B. Norton, B. A. Ridley, H. B. Singh, S. C. Liu, and F. C. Fehsenfeld, Reactive nitrogen species in the troposphere: Measurements of $\mathrm{NO}, \mathrm{NO}_{2}, \mathrm{HNO}_{3}$, particulate nitrate, peroxyacetyl nitrate (PAN), $\mathrm{O}_{3}$, and total reactive odd nitrogen $\mathrm{NO}_{y}$ at Niwot Ridge, Colorado, J. Geophys. Res., 9I, 9781-9793, 1986.

Jaegle, L., et al., Ozone production in the upper troposphere and the influence of aircraft: Evidence for $\mathrm{NO}_{\mathrm{x}}$ saturated conditions, Geophys. Res. Lett., this issue.

Kliner, D. A. V., B. C. Daube, J. D. Burley, and S. C. Wofsy, Laboratory investigation of the catalytic reduction technique for measurement of atmospheric $\mathrm{NO}_{y}$, J. Geophys. Res., 102, 10,759-10,776, 1997.

Koike, M., et al., Impact of aircraft emission on reactive nitrogen over the North Atlantic Flight Corridor, J. Geophys. Res., in press, 1999.

Kondo, Y., M. Koike, S. Kawakami, H. B. Singh, H. Nakajima, G. L. Gregory, D. R. Blake, G. W. Sachse, J. T. Merrill, and R. E. Newell, Profiles and partitioning of reactive nitrogen over the Pacific Ocean in winter and early spring, J. Geophys. Res., 102, 28,405-28,424, 1997a.

Kondo, Y., S. Kawakami, M. Koike, D. W. Fahey, H. Nakajima, Y. Zhao, N. Toriyama, M. Kanada, G. W. Sachse, and G. L. Gregory, The performance of an aircraft instrument for the measurement of $\mathrm{NO}_{y}, J$. Geophys. Res., 102, 28,663-28,671, 1997b.

Miller, T. M., J. O. Ballenthin, R. F. Meads, D. E. Hunton, W. F. Thorn, and A. A. Viggiano, CIMS technique for the measurement of $\mathrm{HNO}_{3}$ in air traffic corridors in the upper troposphere during the SONEX campaign, J. Geophys. Res., in press, 1999.

Parrish, D. D., et al., The total reactive oxidized nitrogen levels and the partitioning between the individual species at six rural sites in eastern North America, J. Geophys. Res., 98, 2927-2939, 1993.

Ridley, B. A., Recent measurements of oxidized nitrogen compounds in the troposphere, Atmos. Environ., 25, 1905-1926, 1991.

Sandholm, S., et al., Summertime partitioning and budget of NO compounds in the troposphere over Alaska and Canada: ABLE 3B, $J$. Geophys. Res., 99, 1837-1861, 1994.

Singh, H. B., and L. J. Salas, Methodology for the analyses of peroxyacetyl nitrate (PAN) in the unpolluted atmosphere, Atmos. Environ., 17, 1507$1516,1983$.

Singh, H. B., A. Thompson, and H. Schlager, SONEX airborne mission and coordinated POLINAT-2 activity: Overview and accomplishments, Geophys. Res. Lett., this issue.

Talbot, R. W., et al., Large-scale distributions of tropospheric nitric, formic, and acetic acids over the western Pacific basin during wintertime, J. Geophys. Res., 102, 28,303-28,313, 1997.

Talbot, R. W., J. E. Dibb, E. M. Scheuer, D. R. Blake, N. J. Blake, G. L. Gregory, G. W. Sachse, J. D. Bradshaw, S. T. Sandholm, H. B. Singh, Influence of biomass combustion emissions on the distribution of acidic trace gases over the southern Pacific basin during austral springtime, $J$. Geophys. Res., 104, 5623-5634, 1999.

Thompson, A. M., L. C. Sparling, Y. Kondo, B. E. Anderson, G. L. Gregory, and G. W. Sachse, Fingerprinting $\mathrm{NO}_{\mathrm{x}}$ on SONEX: What was the aircraft contribution to NO sources?, Geophys. Res Lett, this issue.

J. E. Dibb, E. M. Scheuer, and R. W. Talbot, Institute for the Study of Earth, Oceans, and Space, University of New Hampshire, Durham 03824. (e-mail: jack.dibb@unh.edu; eric.scheuer@unh.edu; robert.talbot@unh.edu)

M. Koike and Y. Kondo, Solar-Terrestrial Environmental Laboratory, Nagoya University, Honohara, Toyokawa, Aichi, 442 Japan. (e-mail: koike@stelab.nagoya-u.ac.jp; kondo@stelab.nagoya-u.ac.jp)

Y. Fukui, L. B. Salas, and H. B. Singh, NASA Ames Research Center, Moffett Field, CA 94035. (e-mail: hsingh@mail.arc.nasa.gov)

J. O. Ballenthin, D. E. Hunton, R. F. Meads, T. M. Miller, and A. A. Viggiano, Air Force Research Laboratory/VSBP, Hanscom Air Force Base, MA01731. (e-mail: ballenthin@plh.af.mil; viggiano@plh.af.mil)

D. R. Blake and N. J. Blake, Department of Chemistry, University of California - Irvine, Irvine, CA 98107. (e-mail: dblake@orion.oac.uci.edu; nblake@uci.edu)

E. Atlas and F. Flocke, Atmospheric Chemistry Division, National Center for Atmospheric Research, Boulder, CO 80303. (e-mail: atlas@acd.ucar.edu)

D. J. Jacob and L. Jaegle, Department of Earth and Planetary Sciences, Harvard University, Cambridge, MA 02138. (e-mail: dij@europa.harvard.edu; lyj@io.harvard.edu)

(Received March 2, 1999; revised June 25, 1999; accepted July 8, 1999.) 